\title{
TINDAK TUTUR REPRESENTATIF DALAM ACARA TALK SHOW MATA NAJWA DI TRANS 7 SEBAGAI ALTERNATIF BAHAN AJAR BAHASA INDONESIA DI SMP
}

\author{
Ari Musdolifah \\ Pendidikan Bahasa dan Sastra Indonesia \\ Universitas Balikpapan \\ Jl. Pupuk Raya, Gn. Bahagia, Balikpapan, Kalimantan Timur \\ Email: ary.musdolifah@uniba-bpn.ac.id
}

\begin{abstract}
ABSTRAK
Penelitian tentang "Tindak Tutur Representatif dalam Acara Talk Show Mata Najwa di Trans 7 sebagai Alternatif Bahan Ajar Bahasa Indonesia di SMP" ini dilatarbelakangi oleh banyaknya tindak tutur yang terjadi dalam kehidupan manusia yang dapat dimaknai berdasarkan konteks. Adapun tujuan dari penelitian ini adalah mendeskripsikan 1) jenis dan tindak tutur representatif dalam acara Talk Show Mata Najwa di Trans 7,2) alternatif tindak tutur representatif dalam acara Talk Show Mata Najwa di Trans 7 sebagai alternatif bahan ajar bahasa Indonesia di SMP. Jenis penelitian ini adalah kuliatif. Pendekatan yang digunakan dalam penelitian ini adalah pendekatan pragmatic. Wujud datanya adalah kata-kata dan kalimat dari tuturan yang dihasilkan oleh Sandiaga Uno Cawapres 2019 dengan nomor urut 02 yang terkait dengan jenis dan fungsi tindak tutur representatif. Sumber data penelitian ini adalah acara Talk Show Mata Najwa yang ditayangkan di Trans 7. Selain itu, teknik pengumpulan data penelitian ini menggunakan teknik simak dna catat untuk selanjutnya di analisis dengan metode padan pragmatis. Berdasarkan hasil dan pembahasan dapat disimpulkan bahwa 1) jenis dan fungsi yang terdapat dalam penelitian ini adalah jenis tindak tutur prediktif, retrodiktif, deskriptif, informatife, konfirmatif, retraktif, dissentif, disputatife, sugestif, dan suppositif, 2) alternatif tindak tutur representatif pada acara Talk Show Mata Najwa yang ditayangkan di Trans 7 sebagai bahan ajar bahasa Indonesia di SMP adalah dapat membantu peserta didik dalam menambah wawasan pengetahuan yang lebih luas tentang jenis dan fungsi tindak tutur representatif dan meningkatkan keterampilan peserta didik untuk memberikan komentar, berfikir kritis, dan kreatif terhadap tuturan tersebut.
\end{abstract}

\section{PENDAHULUAN}

Bahasa dalam kehidupan manusia memiliki peranan yang sanagat penting. Bahasa dalam kehidupan sehari-hari digunakan dalam berkomunikasi. Dalam kesehariannya, manusia menggunakan bahasa sejak bangun tidur, melakukan aktivitas, hingga tidur lagi. Kegiatan tersebut tidak terlepas pada interaksi dengan manusia yang lain. Dalam kegiatan interaksi tersebut manusia saling mengemukakan pendapat, gagasan, ide, dan pandangannya terhadap sesuatu. Hal tersebut sejalan dengan pendapat Achmad \& Alek (2013:10) yang menyatakan bahwa bahasa adalah sistem lambang bunyi yang arbitrer yang dipergunakan para anggota kelompok sosial untuk bekerja sama, berkomunikasi, dan mengidentifikasi diri.

Bentuk komunikasi antara manusia satu dengan dengan yang lain disebut dengan tuturan. Tuturan-tuturan tersebut tidak hanya mengandung kata-kata dan struktur gramatikal saja. tetapi 
mereka juga melakukan tindakan berdasarkan tuturan tersebut. Tindakan-tindakan yang dihasilkan melalui tuturan tersebut dinamakan dengan tindak tutur (Yule, 2006:82). Tindak tutur yang terjadi pada manusia satu dengan manusia yang lain di dalam berbagai situasi kehidupan komunikasi mengarah pada sebuah urutan peristiwa dalam konteks.

Tindak tutur dapat dikaji dengan ilmu pragmatik. Pragmatik adalah studi tentang lebih banyak yang disampaikan daripada yang dituturkan (Yule, 2006:4). Dengan demikian, studi ini dimaksudkan untuk menganalisis tentang apa yang dimaksudkan penutur dengan tuturannya sesuai dengan konteks. Tindak tutur yang terdapat dalam ilmu pragamatik tersebut meliputi, tindak tutur lokusi, ilokusi, dan perlokusi.

Talkshow Mata Najwa yang ditayangkan di Trans 7 pada hari Rabu adalah sebuah acara yang menyajikan pembahasan tentang suatu permasalahan yang sedang diperbincangkan masyarakat. Dalam acara tersebut, terdapat satu, dua sampai tiga orang narasumber yang membahas tentang topik tertentu. Secara langsung, percakapan tersebut menampilkan tuturan-tuturan yang ditanggapi melalui respon positif atau negatif sehingga meghasilkan tindak tutur. Salah satu tindak tutur yang menonjol adalah tindak tutur ilokusi dengan jenis tindak tutur representatif karena tuturan-tuturan tersebut mengandung pernyataan-pernyataan yang sesuai dengan fungsi dari tindak tutur represesentatif. Fungsi-fungsi tersebut meliputi, asertif, prediktif, retrodiktif, deskriptif, askriptif, informatife, konfirmatif, konsesif, retraktif, asentif, dissentif, disputatif, responsif, sugestif, dan suppositif.

Percakapan dalam acara Talk Show Mata Najwa yang ditayangkan di Trans 7 sangat menarik untuk dikaji karena mengandung tuturan-tuturan yang memiliki fungsi dari tindak tutur representatif yang dapat dianalisis secara mendalam. Oleh sebab itu, rumusan msalah dalam penelitian ini adalah 1) jenis dan fungsi tindak tutur representatif pada acara Talk Show Mata Najwa di Trans 7 dengan Tema "Doa Neno dari Lubuk Hati yang Mendalam", 2) alternatif tindak tutur representatif pada acara Talk Show Mata Najwa di Trans 7 dengan Tema "Doa Neno dari Lubuk Hati yang Mendalam” sebagai alternatif bahan ajar bahasa Indonesia di SMP.

\section{METODE}

Jenis penelitian yang digunakan dalam penelitian ini adalah kualitatif. Penelitian kualitatif adalah penelitian yang tidak menggunakan statistik, tetapi dilakukan dengan pengumpulan data analisis dan diinpretasikan (Anggito \& Setiawan, 2018:9). 
Pendekatan yang digunakan dalam penelitian ini adalah pendekatan pragmatic. Pendekatan pragmatik dalam penelitian ini memfokuskan pada bahasa yang digunakan untuk berkomunikasi dalam situasi tertentu. Pemilihan pendekatan ini karena sumber data dalam penelitian ini ada tindak tutur khususnya tindak tutur representatif yang terikat pada konteks.

Data dalam penelitian ini adalah tuturan dari Sandiaga Uno yang merupakan Cawapres nomor urut 02 yang berupa kata-kata dan kalimat. Sementara itu, sumber data dalam penelitian ini adalah acara Talk Show Mata Najwa yang tayang di Trans 7 setiap hari Rabu dengan tema "Doa Neno dari Lubuk Hati yang Mendalam".

Teknik pengumpulan data dalam penelitian ini mengggunakan teknik simak dan catat. Teknik simak dilakukan dengan menyimak acara Talk Show Mata Najwa di Trans 7 untuk menyimak percakapan antara Sandiaga Uno dengan Najwa Sihab dan kemudian diteruskan dengan teknik catat untuk mentranskrip data percakapan yang terjadi pada acara Talk Show Mata Najwa di Trans 7 untuk memudahkan dalam mengklasifikasi dan menganalisis.

Teknik analisis data dalam penelitian ini menggunakan metode padan dengan teknik pragmatis. Dengan demikian, alat penentunya adalah tuturan dari mitra tutur. Penelitian ini mengkaji tuturan yang diutarakan oleh Sandiaga Uno terkait dengan tindak tutur representatif dalam acara Talk Show Mata Najwa di Trans 7 dengan tema "Doa Neno dari Lubuk Hati yang Mendalam".

\section{LANDASAN TEORI}

\section{Pragmatik}

Pragmatik adalah kajian untuk memaknai ujaran-ujaran yang dikemukakan penutur atau mitra tutur melalui bahasa lisan dan tulisan. Pragmatik merupakan ilmu untuk menganalisis makna yang dikomunikasikan oleh pembicara dan diterjemahkan oleh pendengar/pembaca (Yule dalam Yusri, 2016:3). Dengan demikian, makna-makna yang berada dibalik ujaran merupakan studi dalam pragmatik.

Selanjutnya, Nurgiyantoro (2018:26) menjelaskan bahwa pragmatik adalah bidang keilmuan yang sepenuhnya mempelajari tentang komunikasi bahasa antara pembicara dan dipahami oleh lawan bicara. Pemahaman terhadap bahasa sebagai alat komunikasi manusia tidak terlepas dari konteks situasi bahasa itu terjadi.

Berdasarkan beberapa teori tersebut dapat diperoleh pemahaman bahwa pragmatik adalah bidang keilmuan yang digunakan untuk menganalisis makna dari komunikasi bahasa antara 
pembicara dengan pendengar/pembaca. Dengan demikian, seseorang dapat mengontruksi makna yang diutarakan oleh orang lain ketika berbicara.

2. Tindak Tutur

Pragmatik sangat berkaitan dengan tindak tutur. Teori tindak tutur adalah bagian dari pragmatik yang bertujuan untuk mengutarakan dan mengemukakan sebuah tuturan dengan intonasi khusus dan maksud tertentu (Pramesti, 2013:29). Dalam mengkaji tindak tutur, diperlukan konteks sebuah ucapan atau ungkapan untuk memahami maksud sebuah tuturan tersebut.

Austin (Pramesti, 2013:29) membagi tiga klasifikasi tindak tutur, yaitu tindak tutur lokusi (locutionary acts), tindak tutur ilokusi (illocutionary acts), dan tindak tutur perlokusi (perlocutionary acts). Tindak tutur lokusi adalah bentuk tuturan kalimat yang memiliki makna atau referensi ekuivalen dengan arti secara tradisional. Tindak tutur ilokusi adalah pengucapan kalimat tentang pernyataan, tawaran, janji, dan peringatan yang dilakukan oleh penutur. Tindak tutur perlokusi adalah efek yang ditimbulkan oleh tuturan atau pengucapan yang berupa kekaguman, himbauan, dan bujukan.

\section{Fungsi Tindak Tutur Ilokusi}

Sistem klasifikasi umum mencantumkan lima jenis fungsi tindak tutur ilokusi, yaitu deklaratif, representatif, ekspresif, direktif, dan komisif (Yule, 2006:92-94). Penjelasan dari tindak tutur tersebut adalah sebagai berikut.

a. Deklaratatif

Deklaratif adalah jenis tindak tutur yang mengubah dunia melalui tuturan.

b. Representatif

Representatif adalah jenis tindak tutur yang menyatakan apa yang diyakini penutur tentang suatu kasus atau bukan.

c. Ekspresif

Ekspresif adalah jenis tindak tutur yang menyatakan sesuatu yang dirasakan oleh penutur.

d. Direktif

Direktif adalah jenis tindak tutur yang dipakai oleh penutur untuk menyuruh orang lain melakukan sesuatu.

e. Komisif

Komisif adalah jenis tindak tutur yang dipahami oleh penutur untuk mengikatkan drinya terhadap tindakan-tindakan di masa yang akan datang.

4. Jenis dan Fungsi Tindak Tutur Representatif 
Tindak tutur representatif adalah jenis tindak tutur yang menyatakan sesuatu hal yang diyakini penutur atas pernyataan suatu fakta, penegasan, kesimpulan, dan pendeskripsian (Yule, 2006: 92). Tindak tutur ini adalah proses meyakinkan mitra tutur terhadap tuturan yang diyakini oleh penutur. Ibrahim (Pramesti, 2013:39) menyatakan bahwa jenis dan fungsi tindak tutur representatif, yaitu asertif, prediktif, retrodiktif, deskriptif, askriptif, informatife, konfirmatif, konsesif, retraktif, asentif, dissentif, disputatif, responsif, sugestif, dan suppositif.

\section{Konteks Tuturan}

Konteks sangat diperlukan dalam kajian pragmatik karena konteks membantu dalam kegiatan analisis. Hymes (Lubis, 2010:87) mengemukakan adanya faktor-faktor yang menandai terjadinya peristiwa yang disingkat dengan SPEAKING. Masing-masing fonem tersebut dapat dijabarkan sebagai berikut.

a. S

Setting atau scene adalah tenpat bicara dan suasana bicara (ruang diskusi dan suasana diskusi)

b. $\mathrm{P}$

Partisipan yang meliputi pembicara, lawan bicara, dan pendengar. Dalam kegiatan diskusi, partisipan adalah seluruh peserta diskusi.

c. E

End atau tujuan adalah tujuan akhir diskusi

d. A

Act adalah suatu peristiwa ketika seorang pembicara sedang mempergunakan kesempatan bicaranya.

e. $\mathrm{K}$

Key adalah nada suara dan ragam bahasa yanfg dipergunakan dalam menyampaikan pendapatnya dan cara mengemukakan pendapatnya.

f. I

Instrument adalah alat yang digunakan untuk menyampaikan pendapat. Pendapat tersebut dapat secara lisan, tertulis, lewat telepon, dan lain-lain.

g. $\mathrm{N}$

Norma adalah aturan permainan yang harus ditaati oleh setiap peserta diskusi.

h. G 
Genre adalah jenis kegiatan diskusi yang mempunyai sifat-sifat lain dari jenis kegiatan yang lain.

\section{HASIL DAN PEMBAHASAN}

\section{Jenis dan Fungsi Tindak Tutur Representatif Pada Acara Talk Show Najwa di Trans 7 Episode Sandiaga Uno dengan Tema "Doa Neno dari Lubuk Hati yang Mendalam"}

a. Prediktif

Jenis tindak tutur prediktif adalah tuturan yang memiliki maksud memprediksi suatu tuturan dengan keyakinan dan kepercayaan bahwa tuturan tersebut akan terjadi. Fungsi dari tindak tutur representatif dalam jenis tindak tutur prediktif adalah fungsi meramalkan dan memprediksi. Jenis tindak tutur ini tampak pada percakapan antara (N) Najwa Sihab dan (S) Sandiaga Uno ketika membahas tentang target kunjungan kampanye yang dilakukan oleh Sandiaga Uno (S). Percakapan tersebut adalah sebagai berikut.

(1) N: "Dan target sampai selesai, sampai menjelang hari tenang, targetnya berapa banyak?"

\section{S: "Kalau diberi kesehatan, saya mungkin insyaallah bisa kalau kita kita hitung dari titik kunjungan mudah-mudahan bisa mencapai 1500.'}

Pada percakapan (1) di atas, (N) memberikan pertanyaan kepada (S) terkait dengan target kunjungan kampanye. (S) merupakan calon wakil presiden dengan nomor urut 02 dengan calon presidennya adalah Prabowo. Pada saat itu, (S) memberikan tuturan bahwa ia melakukan kunjungan ke sejumlah titik di wilayah Indonesia untuk memperkenalkan dirinya kepada masyarakat. Titik kunjungan yang ingin dicapai adalah 1500, tetapi itu adalah sebuah harapan yang akan dilakukan kalau Ia diberi kesehatan. Hal tersebut didasarkan atas kenyataan bahwa (S) baru menyelesaikan 1250 titik kunjungan. Jawaban atau tuturan dari penutur (S) disepakati oleh (N) dengan mengembangkan pertanyaan yang lainnya.

Maksud dan tujuan tuturan (1) adalah memprediksi kejadin-keadian yang akan akan dilakukan (S) kepada (N). Prediksi tersebut adalah bentuk harapan dan keinginan (S) untuk langkah ke depannya. Dengan mempertimbangkan konteks dan reaksi mitra tutur yang disesuaikan dengan tuturan (1), maka tuturan (1) yang disampaikan oleh penutur (S) dapat diklasifikasikan sebagai salah satu tindak tutur representatif jenis prediksi yang memiliki fungsi memprediksi. Hal itu dikarenakan jenis prediksi merupakan ekspresi kepercayaan dan keyakinan penutur terhadap tuturan 
bahwa tuturan tersebut akan terjadi. Sandiaga Uno (S) meyakini titik kunjungannya dapat mencapai 1500.

\section{b. Retrodiktif}

Jenis tindak tutur retrodiktif adalah tuturan yang memiliki maksud untuk melaporkan suatu kejadian yang telah terjadi. Tuturan tersebut bertujuan untuk membentuk kepercayaan yang sama kepada mitra tutur. Fungsi tindak tutur representatif dalam jenis retrodiktif adalah fungsi memperhatikan dan melaporkan. Hal ini tampak pada percakapan antara Najwa Sihab (N) dan Sandiaga Uno (S) ketika membahas tentang jumlah daerah kunjungan kampanye yang dilakukan oleh Sandiaga Uno (S) sebagai Cawapres 2019 dengan nomor urut 02. Percakapan tersebut adalah sebagai berikut.

(2) N: "Hits banget. Beberapa kali mengundang memang akhirnya baru kesempatan sekarang karena kalau dilihat tadi kesibukan kampanye luar biasa. Sudah keliling beberapa daerah?

S: "Sekarang sudah hampir 1250 titik lokasi kunjungan."

$\mathrm{N}$ : "Wow, 1250

S: "Kalau dihitung keliling lingkar bumi, sudah hampir mencapai 5 kali lingkar bumi."

$\mathrm{N}$ : "Dan, biasanya kalau di setiap daerah banyak sekali titik titik-titik ya, tadi aja contohnya bisa sampai 9-sampai 10 itu."

S: "Iya, kemarin di Maumere ada 5, terus di Kupang ada 4. Jadi, 9 kunjungan ke NTT."

Pada percakapan (2) tersebut, (N) memberikan pertanyaan kepada (S) terkait dengan daerahdaerah kunjungan kampanye. Dengan demikian, (N) menanyakan daerah-daerah yang telah dikunjungi oleh (S). Pada saat itu, (S) menyampaikan tuturan Sekarang sudah hampir 1250 titik lokasi kunjungan (2). Penutur (S) menyampaikan tuturan (2) dengan maksud untuk memberikan laporan dari kejadian yang telah dialami. Selain itu, penutur (S) juga memberikan laporan Kalau dihitung keliling lingkar bumi, sudah hampir mencapai 5 kali lingkar bumi (2). Selain itu, penutur $(\mathrm{N})$ juga memberikan tuturan Kemarin di Maumere ada 5, terus di Kupang ada 4. Jadi, 9 kunjungan ke NTT (2) yang merupakan komentar dari pernyataan $(\mathrm{N})$ terkait dengan responnya terhadap titik-titik kunjungan (S). Laporan yang diberikan oleh (S) kepada (N) adalah laporan kejadian yang telah dialami terkait dengan kampanye Cawapres 2019 dengan nomor urut 02. Penutur (S) memberikan tuturan kepada mitra tutur (N) atas tuturan dari mitra tutur yang 
menyebutkan titik-titik daerah kunjungan kampanye yang dilakukan oleh penutur. Jawaban atau tuturan yang diutarakan oleh $(\mathrm{S})$ membuat ekspresi kagum dari mitra tutur $(\mathrm{N})$.

Maksud dan tujuan tuturan (S) adalah melaporkan kejadian yang telah dialami oleh (S) selama masa kampanye Cawapres 2019 dengan nomoir urut 02. Kunjungan tersebut bertujuan untuk memperkenalkan dirinya kepada masyarakat Indonesia. Dengan mempertimbangkan konteks dan reaksi mitra tutur yang disesuaikan dengan tuturan (2), maka tuturan (4) yang disampaikan oleh penutur dapat diklasifikasikan sebagai salah satu tindak tutur representatif jenis retrodiktif yang memiliki fungsi melaporkan. Hal itu dikarenakan jenis retrodiktif merupakan wujud penutur untuk memberikan laporan kepada mitra tutur atas kejadian yang telah dialami agar mitra tutur mempercayai tuturan yang disampaikan oleh penutur.

c. Deskriptif

Jenis tindak tutur deskriptif adalah mendeskripsikan tuturan kepada mitra tutur dengan maksud untuk menyamakan kepercayaan anatara penutur dan mitra tutur. Tuturan yang dideskripsikan kepada mitra tutur tersebut adalah tuturan yang diyakini dan dipercayai oleh penutur. Fungsi tindak tutur representatif dalam jenis deksriptif adalah fungsi menilai, fungsi menghargai, fungsi mengkategorikan, mengkarakterisasi, mengklasifikasi, mendeskripsikan, mengevaluasi, dan mengidentifikasi. Jenis tindak tutur ini tampak pada percakapan antara (N) dan (S) ketika membahas tentang agenda Prabowo sebagai Capres dan Sandiaga Uno sebagai Cawapres 2019 dengan nomor urut 02 . Percakapannya adalah sebagai berikut.

(3) N: "1500 itu targetnya. tetapi berbanding terbalik dengan Capresnya. Kalau Pak Prabowo, kalau kita lihat agendanya tuh kalau kita bandingkan wartawan tu kan teman-teman kalau kita terima agenda, agendanya Bang Sandi berlembar-lembar, agenda Pak Prabowo cuma 1-2, bahkan terkadang tidak ada agenda. Itu memang strategi atau seperti apa?"

S: "Ya, memang kita menyusun strategi dari awal bahwa Pak Prabowo tingkat pengenalan di masyarakatnya sudah cukup baik dari awal. Sementara saya, di awal kampanye itu ga sampai $\mathbf{4 0 \%}$ yang mengenal Sandi di seluruh Indonesia. Jadi, memang saya ditugasi langsung oleh Pak Prabowo."

N: "Sementara, Pak Prabowo tugasnya?"

Pada percakapan (3) tersebut, $(\mathrm{N})$ memberikan pertanyaan kepada (S) terkait dengan agenda Capres dan Cawapres 2019 dengan nomor urut 02. Mitra tutur (N) memberikan pernyataan bahwa 
agenda (S) berlembar-lembar, sedangkan Capresnya cuma 1-2 dan bahkan tidak memiliki agenda. Pada saat itu, (S) memberikan tuturan bahwa ia belum dikenal oleh masyarakat luas, sedangkan Pak Prabowo sudah dikenal. Jadi, (S) harus mengunjungi titik-titik kunjungan untuk memperkenalkan dirinya sekaligus memberikan solusi ekonomi kepada masyarakat. Penutur (S) menyampaikan tuturan (3) dengan maksud memberikan penjelasan secara detail kepada mitra tutur (N) terkait dengan agenda kerja Capres dan Cawapres 2019 dengan nomor urut 02. Jawaban atau tuturan dari penutur $(\mathrm{S})$ tersebut merupakan jawaban dari pertanyaan mitra tutur $(\mathrm{N})$. Mitra tutur (N) menyepakati dengan beralih kepertanyaan selanjutnya.

Maksud dan tujuan tuturan (3) adalah mengidentifikasi alasan dirinya melakukan kunjungan dibanyak titik kunjungan. Menurut (S), ia merasa bahwa dirinya belum cukup dikenal oleh masyarakat dengan memberikan persentase terkenalan dirinya, yaitu $40 \%$. Dengan mempertimbangkan konteks dan reaksi mitra tutur yang disesuaikan dengan tuturan (3), maka tuturan (3) yang disampaikan oleh penutur dapat diklasifikasikan sebagai salah satu tindak tutur representatif jenis deskriptif yang memiliki fungsi mengidentifikasi. Hal itu dikarenakan jenis deksriptif merupakan tuturan yang dideskripsikan kepada mitra tutur untuk membentuk kepercayaan yang sama kepada penutur.

\section{d. Informatif}

Jenis tindak tutur informatif adalah memberikan informasi kepada mitra tutur agar mitra tutur memiliki kepercayaan yang sama terhadap penutur. Tuturan yang diinformasikan kepada mitra tutur merupakan informasi yang memiliki kebenaran dan dapat dipercaya. Fungsi dari tindak tutur ini adalah fungsi menasehati, mengumumumkan, menginformasikan, menekankan, melaporkan, menunjukkan, dan menceritakan. Jenis tindak tutur ini tampak pada percakapan antara $(\mathrm{N})$ dan $(\mathrm{S})$ ketika membahas tentang tugas-tugas Prabowo sebagai Capres dan Sandiaga Uno (S) sebagai Cawapres 2019 dengan nomor urut 02. Percakapannya adalah sebagai berikut.

(4) N: "Sementara, Pak Prabowo tugasnya?"

S: "Lebih kearah pertemuan-pertemuan yang strategis karena 90\% lebih masyarakat Indonesia sudah mengenal Pak Prabowo. Jadi, tinggal menyampaikan gagasan-gagasannya."

N: “Gagagasan-gagasannya. Mas Sandi, sepanjang masa kampanye ini apapun isu, upaya sosialisasi, tetapi lagi-lagi tampaknya memang yang//yang kerap mengeruak ke public itu politisasi agama." 
Pada percakapan (4) tersebut, $(\mathrm{N})$ yang telah menerima informasi sebelumnya dari (S) bahwa tugas (S) adalah mengunjungi titik-titik kunjungan kampanye untuk memperkenalkan dirinya kepada masyarakat. Kunjungan tersebut dilakukan karena masyarakat hanya 40\% mengenal (S). Dengan demikian, kunjungan kampanye (S) tersebut membuat (S) harus terus keliling wilayah di Indonesia dan menimbukan persepsi dari kalangan wartawan bahwa (S) banyak bekerja, sedangkan Capres 2019 dengan nomor urut 02 tidak bekerja. Oleh sebab itu, (N) bertanya kembali kepada (S) mengenai tugas-tugas Capres 2019 dengan nomor urut 02. Pada saat itu (S) memberikan tuturan bahwa calon Capres nomor urut 02 Pak Prabowo sudah dikenal masyarakat Indonesia sehingga (S) yang merupakan wakil Capres 2019 dengan nomor urut 02 juga bekerja agar masyarakat mnengenalnya. Capres 2019 dengan nomor urut 02 sudah dikenal sehingga ia hanya meneruskan untuk memberikan gagasan-gagasannya saja. Tuturan yang disampaikan oleh (S) kepada mitra tutur (N) berisi tentang pernyataan yang bersifat infomatif terkait dengan tugas-tugas Capres nomor urut 02. Jawaban atau tuturan dari penutur $(\mathrm{S})$ tersebut disetujui oleh $(\mathrm{N})$ dengan mempertegas kata gagasan-gagasan di komentarnya.

Maksud dan tujuan tuturan (4) adalah menginformasikan kepada mitra tutur $(\mathrm{N})$ terkait dengan tugas-tugas Capres 2019 dengan momor urut 02. Hal tersebut ditunjukkan dengan penjelasan dari (S) bahwa memang yang terlihat adalah (S) banyak bekerja karena (S) harus mengunjungi titik-titik kunjungan untuk memperkenalkan dirinya kepada masyarakat. Menurut (S), Capres 2019 dengan nomor urut 02 sudah dikenal oleh masyarakat luas sehingga hanya memberikan gagasangagasannya saja. Dengan mempertimbangkan konteks dan reaksi mitra tutur yang disesuaikan dengan tuturan (4), maka tuturan (4) yang disampaikan oleh penutur dapat diklasifikasikan sebagai salah satu tindak tutur representatif jenis informatif yang memiliki fungsi menginformasikan. Hal itu dikarenakan jenis informatif merupakan informasi yang berupa tuturan dari penutur untuk memperoleh kepercayaan dari mitra tutur karena informasi tersebut dapat dipercaya dan memiliki kebenaran.

e. Konfirmatif

Tindak tutur representatif jenis konfirmatif adalah bentuk ekspresi kepercayaan penutur terhadap sebuah tuturan dan mempercayai bahwa tuturan tersebut merupakan hasil dari langkahlangkah untuk mencari kebenaran yang dilakukan dengan pengamatan, penelitian, dan argumentasi. Fungsi dari jenis tindak tutur konfirmatf ini adalah fungsi menilai, mengevaluasi, menyimpulkan, mengkonfirmasi, mendiagnosa, menemukan, memutuskan, memvalidasi, dan membuktikan. Jenis 
tindak tutur ini tampak pada percakapan antara $(\mathrm{N})$ dan $(\mathrm{S})$ ketika membahas tentang isu agama oleh tataran elite. Percakapaannya adalah sebagai berikut.

(5) N: "Jadi memang itu hanya tataran elite, ditataran elite saja? Menurut Anda, Bang Sandi?"

S: "Menurut saya, ini..ini dari pengalaman saya dan pengalaman saya ini terus kita kompilasi dan apa yang saya pelajari, masyarakat itu menginginkan hal yang paling mendasar. Itu bagaimana mereka mendapatkan penghasilan yang lebih, bagaimana menyikapi keseharian mereka dalam..."

Pada percakapan (5) tersebut, $(\mathrm{N})$ memberikan pertanyaan kepada (S) terkait dengan tataran elite yang menghembuskan isu politik agama kepada masyarakat. Pertanyaan tersebut muncul karena sebelumnya (S) sempat memberi penjelasan tentang kunjungannya ke titik-titik wilayah Indonesia untuk kampanye dan memperkenalkan dirinya kepada masyarakat. Menurut (S), pada saat kunjungan tersebut, ia tidak menemukan isu tersebut di masyarakat karena yang menjadi fokus masyarakat adalah ekonomi. Berdasarkan penjelasan tersebut, $(\mathrm{N})$ meminta penegasan dari (S) terkait dengan isu tersebut. Pada saat itu, (S) menyampaikan tuturan bahwa ia tidak menemukan isu tersebut di masyarakat. Penutur (S) menyampaikan tuturan (5) dengan maksud membuktikan ketidakbenaran isu tersebut dengan memberikan bukti laporan dari masyarakat kepada mitra tutur (N). Jawaban atau tuturan dari penutur $(\mathrm{S})$ tersebut membuat $(\mathrm{N})$ beralih kepada kualitas agama dari Capres 2019 dengan nomor urut 02.

Maksud dan tujuan tuturan (S) adalah membuktikan alasan jawaban yang bersumber dari pengalaman dan kunjungan langsung ke masyarakat. Hal tersebut, membuat jawaban (S) kuat dan relevan. Dengan mempertimbangkan konteks dan reaksi mitra tutur yang disesuaikan dengan tuturan (5), maka tuturan (5) yang disampaikan oleh penutur dapat diklasifikasikan sebagai salah satu tindak tutur representatif jenis konfirmatif yang memiliki fungsi untuk membuktikan. Hal itu dikarenakan jenis konfirmatif merupakan ekspresi kepercayaan penutur terhadap sebuah tuturan berdasarkan kepercayaan penutur melalui pengamatan, penelitian, atau argumentasi yang berupa kebenaran.

\section{f. Retraktif}

Jenis tindak tutur retraktif adalah mengekspresikan suatu tuturan yang tidak lagi dipercaya oleh penutur karena penutur memiliki alasan lain yang lebih dipercaya. Tuturan yang disampaikan oleh 
penutur bertujuan untuk memberikan kepercayaan kepada mitra tutur. Fungsi dari jenis tindak tutur retraktif adalah membenarkan, menyangkal, membantah, menyanggah, dan menarik kembali. Jenis tindak tutur ini tampak pada percakapan antara $(\mathrm{N})$ dan $(\mathrm{S})$ ketika membahas tentang seranganserangan kepada Pak Prabowo sebagai Capres 2019 dengan nomor urut 02 terkait dengan kualitas agama. Percakapan tersebut adalah sebagai berikut.

(6) N: "Kan adalah serangan-serangan. Misalnya, serangan-serangan ke kubu Anda. Pak Prabowo, misalnya diserang, "Wah ini kurang islami, setiap hari Jumat ditanya sholat Jumat di mana? Bisa ngaji atau tidak?" begitu. Bagaimana Anda melihat isu-isu yang seperti ini?"

\section{S: "Isunya menurut saya, isu yang dikembangkan di para politisi, tapi} kalau di masyarakat saya ga pernah ditanya Pak Prabowo sholat Jumat di mana minggu ini?, ga pernah saya ditanya, saya juga ga pernah ditanya. Jangankan Pak Prabowo, saya sendiri juga ga ditanya mengenai eeee..."

Pada percakapan (6) tersebut, (N) memberikan sebuah pertanyaan yang bersumber dari masyarakat terkait dengan kualitas agama Capres 2019 dengan nomor urut 02. Menurut (N), munculnya serangan-serangan ini masih terkait dengan politisasi agama. Kemudian, (N) meminta pendapat dari (S) terkait dengan pertanyaan tersebut. Pada saat itu, (S) menyampaikan tuturan bahwa ia tidak mendapatkan isu tersebut di masyarakat tentang kualitas keagaamaan dari Capres 2019 dengan nomor urut 02. Kemudian, (S) juga memperkuat jawaban dengan tidak adanya pertanyaan terkait dengan kualitas agama tersebut terhadap dirinya. Penutur menyampaikan tuturan (6) dengan maksud untuk membantah isu-isu yang dikembangkan oleh masyarakat karena menurut (S) isu tersebut tidak ditemukannya di masyarakat. Jawaban atau tuturan dari penutur (S) tersebut membuat $(\mathrm{N})$ tidak bertanya lagi tentang isu yang terdapat di masyarakat, tetapi $(\mathrm{N})$ beralih dengan pertanyaan asal mula munculnya isu tersebut.

Maksud dan tujuan tuturan (6) adalah membantah pernyaaatan yang disampaikan oleh (N). Hal tersebut ditunjukkan dengan reaksi tenang (S) dalam menjawab pertanyaan. Menurut (S), isu tersebut tidak ditemukannya di masyarakat dan juga pada dirinya. Dengan mempertimbangkan konteks dan reaksi mitra tutur dengan tuturan (6), maka tuturan (6) yang disampaikan oleh penutur dapat diklasifikasikan sebagai salah satu tindak tutur representatif jenis retraktif yang memiliki fungsi untuk membantah. Hal itu dikarenakan jenis retraktif merupakan eskpresi tuturan yang tidak dapat dipercaya oleh penutur karena penutur memiliki alasan lain yang lebih dipercaya. 


\section{g. Dissentif}

Jenis dissentif merupakan ekspresi tuturan yang menjelaskan bahwa penutur tidak mempercayai kebenaran tuturan yang sebelumnya. Penutur mengungkapkan ketidakpercayaannya agar mitra tutur juga memiliki ekspresi yang sama terhadap penutur. Fungsi tindak tutur dissentif ini adalah fungsi membedakan dan fungsi menyatakan tidak setuju. Jenis tindak tutur ini tampak pada percakapan antara $(\mathrm{N})$ dan $(\mathrm{S})$ ketika membahas tentang isu-isu kualitas agama dari Capres 2019 dengan nomor urut 02. Percakapannya adalah sebagai berikut.

(7) N: "Jadi memang elite kita saja ni yang suka//suka//memanfaatkan isu itu?"

S: "Ya, saya juga ga mau menuduh ya, tapi menurut saya isu itu jauh sekali dan inilah disconnect yang saya melihat. Jakarta dan seluruh//pelosok Indonesia itu ada disconnect dan saya sebut sebagai great disconnect dan saya dapat itu begitu turun ke masyarakat. Saya waktu ke 600-700 titik kunjungan saya bertanya gitu pada temen-temen yang ada di BPN, "Ini kalian, issue yang terus dibaca di online itu ga nyambung loh dengan apa yang dirasakan masyarakat, masyarakat itu maunya simple sekali, gitu dan sebutnya referendum ekonomi." Pilpres 2019 ini, 17 april pilihannya sangat simpel, bagaimana mereka menyikapi keadaan mereka dalam kehidupan sehari-hari. Kalau mereka happy ya tentunya mereka akan memilih//pertahanan, tetapi kalau mereka ingin perbaikan, ingin perubahan ekonomi yang lebih baik..."

$\mathrm{N}$ : "Akan memilih penantang?"

S: "Prabowo Sandi menawarkan satu solusi."

Pada percakapan (7) tersebut, $(\mathrm{N})$ memberikan pertanyaan kepada (S) terkait dengan isu yang dikembangkan oleh para elite. Isu tersebut adalah terkait dengan politisasi agama. Sebelumnya, (N) sempat bertanya kepada (S) tentang politisasi agama dan (S) menjawab kalau ia tidak menemukannya di masyarakat. Masyarakat hanya bertanya tentang ekomomi. Dan akhirnya, (N) meminta kepastian lagi kepada (S) atas itu bahwa para elite suka memanfaatkan isu tersebut. Pada saat itu, (S) menyampaikan tuturan bahwa ia tiak dapat menuduh langsung bahwa para elite yang menyebarkan isu itu. Jawaban yang dikemukakan (S) adalah jawaban yang dilandasakan dari hasil kunjungannya ke titik kunjungan selama kampanye, yaitu ia tidak menemukan isu itu di 
masyarakat. Masyarakat hanya membahas tentang permsalahan ekonomi. Penutur (S) menyampaikan tuturan (7) dengan maksud untuk memberikan pernyataan tidak setuju terhadap pernyataan dari $(\mathrm{N})$ terkait dengan isu yang dikembangkan oleh para elite. Jawaban atau tuturan dari penutur (S) diterima dengan tidak memberikan pertanyaan lagi dengan konteks masyarakat, tetapi beralih ke konteks doa oleh Neno Warisman.

Maksud dan tujuan tuturan (S) adalah memberikan pernyataan tidak setuju terhadap pernyataan (N) terkait dengan isu para elite tentang politisasi agama. Hal tersebut ditunjukkan dengan sikap tenang $(\mathrm{S})$ saat menjawab pernyataan dna pertanyaan dari $(\mathrm{N})$. Sikap tenang $(\mathrm{S})$ saaat menjawab tersebut karena (S) telah memiliki bukti langsung dari masyarakat. Dengan memepertimbangkan konteks dan reaksi mitra tutur yang disesuaikan dengan tuturan (7), maka tuturan (7) dapat diklasifikasikan sebagai salah satu tindak tutur representatif jenis dissentif yang memiliki fungsi untuk menyatakan tidak setuju. Hal itu dikarenakan jenis dissentif merupakan eskspresi ketidakpercayaan penutur atas tuturan sebelumnya.

h. Disputatif

Dalam jenis disputative, penutur mengekspresikan tuturannya dengan maksud agar mitra tutur membentuk kepercayaan yang serupa terhadap protes atau sikap keberatan yang disampaikan oleh penutur karena tuturan tersebut tidak sesuai dengan apa yang diyakini penutur. Fungsi dari jenis tindak tutur disputatif adalah fungsi berkeberatan, memprotes, dan mempertanyakan. Jenis tindak tutur ini tampak pada percakapan antara $(\mathrm{N})$ dan $(\mathrm{S})$ ketika membahas tentang isu politisasi agama. Percakapan tersebut adalah sebagai berikut.

(8) N: "Di situ merebak dari mulai awal kampanye sampai sekarang dan khawatir sampai selesai pun akan seperti itu. Bagaiman Anda melihatnya?"

S: "Saya tuh di 1250 titik kunjungan dan banyak temen-temen yang ngikutin melalui di Instagram, jarang sekali ditanyai mengenai issue agama. Selalu ditanya mengenai lapangan pekerjaan, ditanya mengenai harga harga bahan pokok, ditanya mengenai pendidikan, bagaimana dengan biaya kesehatan, biaya listrik paling sering ditanya juga, bagaimana strategi Prabowo Sandi untuk menghadirkan biaya hidup yang lebih terjangkau, bagaimana strategi swasembada pangan, bagaimana kebijakan untuk para petani, nelayan, itu yang lebih sering. Masalah agama ini saya juga bingung gitu kenapa terus menerus ke luar di percakapan elite, di percakapan kalau kita melihat timeline. 


\section{Padahal, kalau langsung terjun ke masyarakat, kami mengumpulkan data yang terus kita kompilasi, hampir tidak pernah ditanya mengenai issue agama."}

Pada percakapan (8) tersebut, $(\mathrm{N})$ memberikan pertanyaan kepada $(\mathrm{S})$ terkait isu agama yang bernama "politisasi agama". Isu tersebut beredar di tengah masyarakat dan selalu dibicarakan daripada pembicaraan tentang kunjungan ke titik-titik daerah kampanye. Mendengar pernyataan dari $(\mathrm{N})$, (S) merasa bingung karena ketika Ia melakukan kunjungan kampanye ke 1250 titik wilayah Indonesia, Ia tidak menemukan pertanyaan terkait dengan isu agama. Hal-hal yang ditanyakan oleh masyarakat adalah seputar ekonomi karena (S) selalu fokus kepada ekonomi di setiap kunjungannya. Jawaban atau tuturan dari penutur (S) tidak diperpanjang lagi oleh mitra tutur $(\mathrm{N})$ dengan beralihnya pertanyaan yang diberikan oleh mitra tutur $(\mathrm{N})$ tentang aqsal mula munculnya isu tersebut.

Maksud dan tujuan tuturan (8) adalah memberikan penjelasan kepada (N) bahwa (S) merasa mempertanyakan pernyataan yang dikemukakan oleh $(\mathrm{N})$. Tuturan yang diberikan oleh $(\mathrm{N})$ sangat jarang sekali ditemukan di masyarakat. Oleh sebab itu, (S) merasa bingung dengan adanya pernyataan terkait tentang isu politisasi agama. Dengan memperhatikan konteks dan tuturan dari tuturan (8), maka tuturan (8) yang disampaikan oleh penutur dapat termasuk ke dalam jenis tindak tutur representatif dengan jenis disputatif yang memiliki fungsi untuk mempertanyakan. Hal itu dikarenakan jenis disputatif merupakan ekspresi kepercayaan bahwa terdapat alasan yang kuat untuk tidak mempercayai suatu tuturan kepada mitra tutur agar mitra tutur percaya pada alasan lain yang diyakini oleh penutur.

i. Sugestif

Dalam jenis sugestif, penutur mengekspresikan tuturannya agar mitra tutur membentuk kepercayaan yang sama terhadap saran dan jawaban yang disampaikan oleh penutur karena penutur meyakini bahwa hasilnya akan lebih baik. Fungsi dari jenis tindak tutur responsif adalah fungsi menerka, menebak, berhipotesis, berspekulasi, dan menyarankan. Jenis tindak tutur ini tampak pada percakapan antara $(\mathrm{N})$ dan $(\mathrm{S})$ ketika membahas tentang cuplikan video yang ditayangkan oleh program talk show Mata Najwa terkait dengan kegiatan kampanye Neno Warisman Wakil Ketua Badan Pemenangan (BPN) Prabowo Sandi. Percakapannya adalah sebagai berikut.

(9) N: "Jadi, itu berpotensi disampaikan di ruang public oleh seorang politisi?" 


\section{S: "Kalau saya sampaikan kepada kita semua marilah kita bijak melihat setiap//baik itu doa, ungkapan, dan lain sebagainya dikembalikan ke proporsinya masing-masing. Bangsa ini betul betul perlu satu narasi} baru, menurut saya. Karena kalau kita liat, ini narasi TV ya? Ini narasi TV ya?"

N: "Mata Najwa ini."

Pada percakapan (9) tersebut, sebelum (N) bertanya kepada (S), (N) sempat menayangkan video kampanye Neno Warisman pada tanggal 21 Februari 2019. Neno Warisman adalah seorang Wakil Ketua Badan Pemenangan (BPN) dari Prabowo dan Sandi. Kegiatan kampanye tersebut menjadi viral karena terdapat doa yang dibacakan oleh Neno Warisman dengan berurai air mata. Berdasarkan video tersebut, (N) menyatakan bahwa doa tersebut memunculkan interpretasi bagi masyarakat karena akhirnya dikaitkan dengan politik dan agama. Oleh sebab itu, (N) mempertanyakan doa tersebut kepada (S) terkait dengan pembacaan doa tersebut dari segi tempat dan politik. Mendengar pertanyaan dari $(\mathrm{N})$, (S) menjawab dengan lebih mengarah kepada saran kepada masyarakat untuk dapat berpikir positif tentang hal-hal baik di sini konteksnya adalah agama dan tidak berpikir negatif atas hak setiap individu dalam berdoa. Jawaban atau tuturan (S) tersebut disepakati oleh mitra tutur $(\mathrm{N})$ dengan mengembangkan pertanyaan yang lainnya.

Maksud dan tujuan (9) adalah menghargai doa yang diutarakan oleh Neno Warisman Wakil Ketua Badan Pemenangan ketika melakukan kampanye. Hal tersebut membuat mitra tutur (N) tidak mempertanyakan lagi topik tentang doa tersebut kepada (S) karena (S) memberikan jawaban secara umum dan positif terkait dengan hak asasi individu dalam berdoa dengan tenang. Dengan mempertimbangkan konteks dan reaksi mitra tutur yang disesuaikan dengan percakapan (9), maka tuturan (9) yang disampaikan oleh penutur dapat termasuk ke dalam tindak tutur representatif dengan jenis sugestif yang memiliki fungsi menyarankan. Hal itu dikarenakan jenis tindak tutur sugestif merupakan tuturan yang ditujukan kepada mitra tutur agar mitra tutur meyakini tuturan yang berisi saran dari penutur tersebut.

\section{j. $\quad$ Suppositif}

Dalam jenis suppositif, penutur mengekspresikan tuturannya dengan maksud agar mitra tutur membentuk kepercayaanyang serupa terhadap tuturan atau asumsi yang disampaikan oleh penutur melalui pertimbangan dari berbagai macam konsekuensi. Fungsi tindak tutur suppositif adalah fungsi mengasumsikan, berhipotesis, mempostulasikan, menstipulasikan, memperkirakan, dan 
berteori. Jenis tindak tutur ini tampak pada percakapan antara $(\mathrm{N})$ dan $(\mathrm{S})$ ketika membahas tentang interpretasi masyarakat terkait dengan doa yang diutarakan Neno Warisman Wakil Ketua Badan Pemenangan (BPN) dari Prabowo Sandi pada saat kampanye tanggal 21 Februari 2019. Percakapannya adalah sebagai berikut.

(10) N: "Bahwa kemudian interpretasi yang muncul yang kemudian ramai, orang menyesalkan karena kemudian mengkait-kaitkannya dengan politik, agama// dan itu kan disampaikan oleh wakil ketua badan pemenangan Anda."

\section{S: "Ya, tentunya interpretasi masyarakat itu kita serahkan kepada masing-masing anggota masyarakat, tapi kalau saya lihat..."}

N: "Kalau interpretasi Anda apa, Bang Sandi?"

Pada percakapan (10) tersebut, (N) memberikan pernyataan terkait dengan doa yang disampaikan oleh Neno Warisman pada saat kampanye. Menurut $(\mathrm{N})$, doa tersebut membuat masyarakat memiliki interpretasi yang berbeda-beda yang kemdian dikaitkan dengan politik dan agama. Hal tersebut membuat $(\mathrm{N})$ memberikan pertanyaan kepada $(\mathrm{S})$ atas menyemaraknya isu tersebut.pada saat itu, (S) menjawab pernyataan dan pertanyaan $(\mathrm{N})$ dengan tenang dan memberikan jawaban secara spesifik terkait isu agama dan politik tersebut. Menurut (S), isu yang berkembang di masyarakat yang kemudian menimbulkan interpretasi yang berbeda-beda tersebut itu wajar dan sah saja. Selanjutnya, (N) juga menambahkan bahwa setiap masyarakat bebas memiliki pendapat sendiri terhadap suatu isu. Jawaban atau tuturan dari penutur $(\mathrm{S})$ tersebut membuat $(\mathrm{N})$ tidak memberikan pertanyaan lagi terkait dengan interpretasi masyarakat, tetapi langsung memberikan pertanyaan kepada $(\mathrm{S})$ tentang pendapatnya terhadap isu tersebut.

Maksud dan tujuan tuturan (10) adalah memberikan sebuah asumsi kepada (N) terhadap pernyataan dan pertanyaan yang diajukan oleh $(\mathrm{N})$. Menurut $(\mathrm{S})$, ia tidak dapat memberikan jawaban yang pasti terhadap jawaban-jawaban dari pemikiran masyarakat karena itu hak dari masing-masing orang. Dengan mempertimbangkan konteks dan reaksi mitra tutur yang disesuaikan dengan tuturan (10), maka tuturan (10) yang disampaikan oleh penutur dapat termasuk tindak tutur representatif jenis suppositif yang memiliki fungsi untuk mengasumsikan. Hal itu dikarenakan jenis suppositif adalah suatu ekspresi tuturan melalui pertimbangan konsekuensi-konsekuensi agar mitra tutur memiliki kepercayaan yang sama terhadap tuturan dari penutur. 
Berdasarkan uraian dari hasil dan pembahasan tersebut, dari 15 jenis dari tindak tutur representatif yang meliputi, asertif, prediktif, retrodiktif, deskriptif, askriptif, informatife, konfirmatif, konsesif, retraktif, asentif, dissentif, disputatif, responsif, sugestif, dan suppositif yang terdapat dalam penelitian ini adalah jenis tindak tutur prediktif, retrodiktif, deskriptif, informatife, konfirmatif, retraktif, dissentif, disputatife, sugestif, dan suppositif. Dengan demikian, tuturan (S) tidak mengarah kepada tindak tutur representatif jenis asentif, asertif, askriptif, konsesif, dan responsif.

\section{Tindak Tutur Representatif sebagai Alternatif Bahan Ajar Bahasa Indonesia di SMP}

Pembelajaran tindak tutur representatif yang terdapat pada acara Talk Show Mata Najwa dapat digunakan sebagai bahan ajar sesuai dengan materi pelajaran dialog interaktif pada kelas IX SMP. Dialog interaktif yang terdapat pada kelas IX SMP ini memiliki KD 1.2 Mengomentari pendapat narasumber dalam dialog interaktif pada tayangan televise/siaran radio. Tuturan yang mengandung jenis tuturan representatif dapat digunakan sebagai bahan ajar dalam mengomentari dialog interaktif pada acara Talk Show Mata Najwa dengan berbagai topik yang sedang hangat diperbincangkan.

Tuturan-tuturan yang diutarakan baik dari narasumber atau dari peserta dialog pada acara Talk Show Mata Najwa yang merupakan tuturan representatif dapat dilihat pada tema, materi, tanggapan, dan jawaban. Proses mengomentari dialog interaktif tersebut didasarkan pada penting tidaknya tema dalam dialog, kemampuan dan penguasaan para narasumber terhadap materi yang dibicarakan, relevan atau tidaknya pertanyaan peserta dialog terhadap tema dialog, dan benar atau tidaknya tanggapan atau jawaban narasumber atau pertanyaan peserta dialog.

Berdasarkan jenis-jenis tuturan representatif dalam dialog interaktif acara Talk Show Mata Najwa, maka peserta didik dapat memberikan komentarnya tentang pemakaian jenis tuturan pada dialog tersebut. Komentar tersebut dapat setuju atau tidak tergantung dari benar tidaknya ketepatan dalam tuturan. Oleh sebab itu, banyaknya tuturan pada dialog interaktif pada acara Talk Show Mata Najwa dapat membantu peserta didik dalam menambah wawasan pengetahuan yang lebih luas tentang jenis dan fungsi tindak tutur representatif dan meningkatkan keterampilan peserta didik untuk memberikan komentar, berfikir kritis, dan kreatif terhadap tuturan tersebut. Dengan demikian, guru dapat menerapkan penggunaan tindak tutur representatif dalam materi pembelajaran dialog interaktif melalui acara Talk Show Mata Najwa. 


\section{SIMPULAN}

Penelitian ini menggunakan teori Pragmatik khususnya jenis dan fungsi tindak tutur representatif dalam memahami tindak tutur acara Talk Show Mata Najwa yang ditayangkan di Trans 7. Berdasarkan hasil analisis dapat disimpulkan bahwa jenis dan fungsi yang terdapat dalam penelitian ini adalah jenis tindak tutur prediktif, retrodiktif, deskriptif, informatife, konfirmatif, retraktif, dissentif, disputatife, sugestif, dan suppositif. Dengan demikian, tidak terdapat tindak tutur yang mengarah kepada tindak tutur representatif jenis asentif, asertif, askriptif, konsesif, dan responsif.

Selain itu, alternatif tindak tutur representatif pada acara Talk Show Mata Najwa yang ditayangkan di Trans 7 sebagai bahan ajar bahasa Indonesia di SMP adalah dapat membantu peserta didik dalam menambah wawasan pengetahuan yang lebih luas tentang jenis dan fungsi tindak tutur representatif dan meningkatkan keterampilan peserta didik untuk berfikir kritis dan kreatif terhadap tuturan tersebut. Dengan demikian, peserta didik dapat memberikan komentarnya terhadap jenis dan fungsi tindak tutur representatif yang terdapat pada acara tersebut.

\section{DAFTAR RUJUKAN}

Achmad \& Alek Abdullah. 2013. Linguistik Umum. Jakarta: Erlangga.

Anggito, Albi \& Johan Setiawan. 2018. Metode Penelitian Kualitatif. Sukabumi: CV Jejak.

Lubis, Hamid Hasan. 2011. Analisis Wacana Pragmatik. Bandung: Angkasa.

Nugiyantoro, Burhan. 2018. Stilistika. Yogyakarta: Gadjah Mada University Press.

Pramesti, Swesti Intan. 2013. Tindak Tutur Representatif dalam Film Le Fabuleux Destin D'Amelie Poulain Karya Jean Pierre Jeunet dan Guillaume Laurant. Skripsi. Fakultas Bahasa dan Seni, Universitas Negeri Yogyakarta.

Yule, George. 2006. Pragmatik. Yogyakarta: Pustaka Pelajar.

Yusri. 2016. Ilmu Pragmatik dalam Perspektif Kesopanan Berbahasa. Yogyakarta: Deepublish. 